UDC 622.673 .6

\title{
鋼索に生ずる最大曲げ応力についで
}

$\begin{array}{llll}\text { 正会員 会 } & \text { 田 俊 } \text { 夫 }^{* *} \\ \text { 正会員 } & \text { 佐 } & \text { 藤 } & \end{array}$

\section{On the Maximum Bending Stress of Wire Ropes}

Toshio AIDA and Susumu SATO

\begin{abstract}
We have measured by the bending test the bending stress of wire ropes, which has now been discussed for about a century. As the results of the experiment, we have concluded following:

1) Not only each wire in a wire rope slips along each other, but also the section of the ropeis deformed in accordance with its bending.

2) The value of bending stress is not the same at different parts of the section of the rope, but it shows variation at each part of the section. The variation seems to be caused by the separation and deformation of the section.

3) We have found that the value of bending stress hitherto measured and considered the maximum is not the largest, but cather the minimum or one of the smallest values.

4) The modulus of elasticity for bending stress $E_{b}$ amount to nearly $20,000 \mathrm{~kg} / \mathrm{mm}^{2}$ for maximum bending stress in our experiment.

Our conclusion is that we should adopt $E_{b}=20,000 \mathrm{~kg} / \mathrm{mm}^{2}$ instead of $E_{b}=10,000 \mathrm{~kg} / \mathrm{mm}^{2}$, which is adopted in the regulation for safety of mining in our country.
\end{abstract}

\section{1. 緒}

鋼索を曲げたときに鋼索素線にどのような応力が生ず るかという問題は, 鋼索の寿命のみならず鋼荣の安全率 を規定する際にも直接関係するので, 古くより種々論議 されてきた。

すなわちまず1861年に Reuleaux は鋼索の曲げ応力に 関して

$$
\begin{aligned}
& \sigma_{b}=E \frac{d}{D} . \\
& \sigma_{b} \text { : 曲代応力, } E \text { : 素線の弾性率 } \\
& D \text { : シーブ径, } d: \text { 素線径 }
\end{aligned}
$$

といら式を提唱した。

ところが Bach とその協力者 は1881年から1924年に かけてこの式に根気強く反対し“修正係数 $3 / 8 ”$ 子かけた。 この值は十分な理論的根拠がなかつたにもかかわらず， ほとんどすべての便覽ばかりか巻索に関する法規にまで 採用されるに至つたので 1915年に Benoit ${ }^{2)}$ が詳細に指 摘しているよらに鋼索計算に不正確性と混乱がもたらさ れたのである。

その後 Hrabák $^{3)}$, Isaachsen ${ }^{4}$, Bock $^{5}$ )がこの分野に

* 昭和 35 年 6 月 14 日受理

** 工博 京都大学教授 鉱山学教室

*** 工博 京都大学助手 鉣山数学室
おける理論的研究に貢献し, Reuleaux の式においてE の代りに $E \cos ^{2} \omega_{r} \cdot \cos ^{2} \omega_{s}$ （ $\omega_{r}:$ ロープ然り角, $\omega_{s}:$ ス トランド然り角) とおくべきことを提案した (以下鋼荣 の曲げ虑力に対するこの係数を，素線の弾性率 $E$ と区別 して鋼索の曲げ応力弾性率と呼び, $E_{b}$ に表わすことと す方)。

一方穾験的研究としてはBenoitとその協力者Woernle の行つた鋼索の曲げ疲労試験結果がある。この 2 人の研 究者は1915年彼等の詳細な実験結果より，鋼索素線の曲 げ応力は Reuleaux の方程式に相応するものより小さく なく,かえつて大きいことを発表した。その後もWoern$1 \mathrm{e}^{6)}$ の指導下のドイツ鋼索委員会によつて(1929年), 委 た Scoble ${ }^{7)}$ の指導下のイギリス鋼索委員会によつて, 種々の方法で多くの曲げ疲労試験が実施された。しかし この実験では素線に作用する主な応力を決定するに至ら なかうた。

わが国における研究としては理論的方面では1951年の 池田博士，上野8)の撚線ばねより出発した理論式がある。 この結果は大体 $E_{b}=20,000 \mathrm{~kg} / \mathrm{mm}^{2}$ とおくへきことを示 している。

実験的研究も水田博士 ${ }^{9}$ をはじめ小川博士 ${ }^{10)}$, その他 によつて行われたが，鋼索の曲げ疲労試験においては引! 張り, 曲げ応力以外に捩り, 接触応力あるいは製作時っ 
残留応力等複雑な応力をうけるので，曲げ応力の影響だ けを導きだしその值を確定することには困難があつたよ うである。しかし水田博士の実験結果で $E_{b} \doteqdot E と い う$ 結 果が推定されていることは注目すべきである。

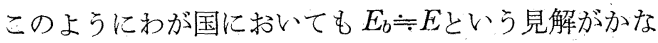
り有力でありながら，なお明瞭に直接的に曲げ応力の測 定結果より $E_{b}$ の值を決定することができていないため $E_{b}=10,000 \mathrm{~kg} / \mathrm{mm}^{2}$ という值が現在まだ使用されている のである。しかるに近年になつて局部応力を測定するに 便利な電気抵抗線ヒズミ計が急速に発達したので，筆者 らはとくに小寸法のヒズミ計（たとえば長さ $4 \mathrm{~mm}$ ，巾 $0.7 \mathrm{~mm}$ ) 孝用いて鋼索の曲げ応力の直接測定を試み(1953 年〜1959年），この結果 $6 \times 7$ 鋼索で $E_{b}=10,000 \sim 16,000$ $\mathrm{kg} / \mathrm{mm}^{2}$ の值を得た ${ }^{11)}$ 。同様な実験が $\mathrm{Wyss}^{12}$ )によつて Huggenberger ヒズミ計 (ケージ長 $10 \mathrm{~mm}$ ) を用いて行 われたが，張力作用下の横荷重による曲げ試験では筆者 らと同様の值が得られたようである。

この值は筆者らにとつて予期したものより小さいもの であつた。なぜなら素線相互の摩擦を無視して誘導した 理論值 $E_{b}=E \cos ^{2} \omega_{r} \cdot \cos ^{2} \omega_{s}{ }^{13)}$ よりも実際の場合は素 線相互の摩擦の作用によつて大きくなければならず, $E_{b}$

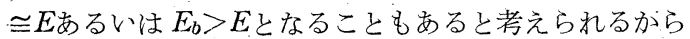
である。一方ヒズミ計の寸法と素線の寸法, 曲率等の関 係より測定結果がある範囲のヒズミの平均值を表わすた め $E_{b}$ の值が多少小さい目にでることも考えられるが; 線径に対して十分小さいヒズミ計を使用することにより， また素線の曲率半径の小さい普通撚り鋼索の $E_{b}$ の測定 值が曲率半径の大きい対応するラング撚りの $E_{b}$ の測定 值より大きい事実などよりして，これらの響影は $E_{b}$ の 測定値の過少を説明するにはあまりに小さいことは検討 お゙みである。

そこで筆者らは今まで測定していた個所が最大曲げ応 力発生個所ではないのではないか，曲げの際鋼索の断面 変形が生じこれが素線間の滑りに伴う断面分離の順序と 相まつて，鋼索断面中の位置によつて曲げ応力が大きく なる個所と小さくなる個所を生じるのではないか，今ま で測定していた個所は曲げ応力が小さくなる個所ではな いかと考えて本研究に着手した。

その結果一応満足す心゙きものを得, 鋼索の曲げ応力に 関して決定版に近いものを見いだしえたと考えられるの でここに発表する次第である。

なお参考として現在用いられている $E_{b}$ の值を示せば 次のようである。
a) $E_{b}$ $=2.0 \times 10^{4} \mathrm{~kg} / \mathrm{mm}^{2}$

(運輸省新索道規則)

b) $E_{b}=E \cos ^{2} \omega_{r} \cdot \cos ^{2} \omega_{s}=1.9 \times 10^{4} \mathrm{~kg} / \mathrm{mm}^{2}$

c) $E_{b}=E \cos ^{4} \omega_{r} \cdot \cos ^{4} \omega_{s}=1.7 \times 10^{4} \mathrm{~kg} / \mathrm{mm}^{2}$
(ソ連で使用)
d) $E_{b}=\frac{1}{2} E$
$=1.0 \times 10^{4} \mathrm{~kg} / \mathrm{mm}^{2}$
(鉱山保安規則)
e) $E_{b}=\frac{3}{8} E$
$=0.8 \times 10^{4} \mathrm{~kg} / \mathrm{mm}^{2}$ (Bach)

\section{2. 試験方法と測定結果}

\section{$2 \cdot 1$ 横荷重を加える引張り曲げ試験}

$2 \cdot 1 \cdot 1$ 試料と試験方法 試験には第1図に示すよう な 4 点支持中央荷重による引張り曲げ試験装置を用いた。 引張り荷重 $S$ はウォーム・ギヤ定利用する引張り置装に よつて与えられ, 横荷重 $Q$ は挺子を利用する負荷装置に よつて加えられる。横荷重 $Q$ の変化とともに張力 $S$ も変 化するが，試験中常に一定值を保つようにウォーム・ギ ヤによつて正確に調節される。撓み $y$ はダイヤル・イン ジケータによつて読みとる。電気抵抗線ヒズミ計は横荷 重作用点下の各素線に素線軸に平行にはりつける。使用 したヒズミ計は新興通信製の $\mathrm{S}_{121} \mathrm{~B}(60 \Omega$, 長さ $4 \mathrm{~mm}$, 巾0.7mm)で，接着剤は新興通信製 $K-4$ である。

鋼索の曲げ剛性は素線相互の滑りの程度に依拠するの で鋼索の全長にわたつて一定ではなく，負荷点近傍で小 さくなるものと考えられるが，以ま鋼索の曲げ剛性をそ の全長にわたつて一定とすると次式が成立する。

$$
\begin{aligned}
& y= \frac{Q}{2 S}\left[\left(\frac{l}{2}-\frac{\sinh \frac{\lambda l}{2}}{\lambda \cosh \frac{\lambda l}{2}}\right)-\left(l_{1}-\frac{\sinh \lambda l_{1}}{\lambda \cosh \frac{\lambda l}{2}}\right)\right. \\
&\left.\left\{\begin{array}{c}
l_{1}-\frac{\sinh \lambda l_{1}}{\lambda} \cdot \frac{2 e^{\frac{\lambda l}{2}}}{1+e^{\lambda l}} \\
l_{1}-\frac{\sinh \lambda l_{1}}{\lambda} \cdot \frac{e^{\lambda l}\left(1+e^{\lambda l}\right)}{1+e^{\lambda l}}
\end{array}\right\}\right) \ldots \ldots \ldots \cdots \cdot(2) \\
& \text { ここで } \lambda \sqrt{\frac{S}{E_{f} I_{r}}} .
\end{aligned}
$$

$E_{f}:$ 鋼索の曲げ岡性弾性率

$I_{r}:$ 鋼荣の断面二次亡ーメント

(2) 式は $l_{1}, l_{2}$ の大きさに応じて近似計算を行らこと ができる。

入が比較的大きいときは

$$
y \cong \frac{Q}{2 S}\left\{\frac{l_{2}}{2}-l_{1}(K-1)-\frac{1}{\lambda}\left(1-K e^{\frac{-\lambda 1}{2}}\right)\right.
$$

$\lambda$ が比較的小さいときはKの代りに原をおく。

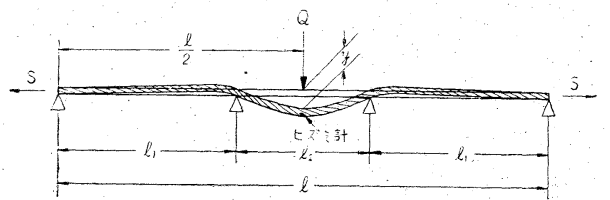

第 1 図 引張り曲げ試験装置(I) 


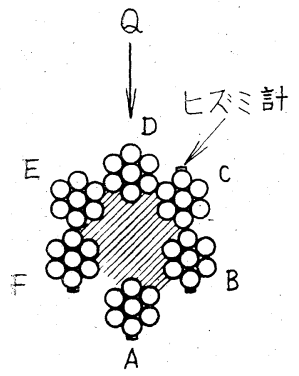

(a)

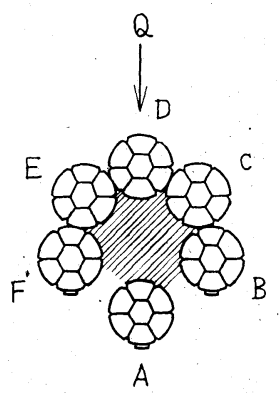

(b)
第2図，ヒズミ計貼付位置拉よび断面の分離と 変形状態を示寸図

ここで

$$
K=\frac{\lambda l_{1}-e^{\frac{-\lambda l_{2}}{2}}}{\lambda l_{1}-\frac{1}{2}}, \quad K^{\prime}=\frac{\lambda l_{1}-e^{\frac{-\lambda l_{2}}{2}}}{\lambda l_{1}-\frac{1+e^{-\lambda l_{2}}}{2}}
$$

（3）式によつて入を図式解法を用いて求めることが でき， $\lambda$ から鋼索の曲价剛性 $E_{f} I_{r}$ を求めることができ る。

\section{横荷重作用点の曲率 $1 / \rho$ は}

$$
\begin{gathered}
\frac{1}{\rho}=-\frac{Q}{2 S} \lambda\left(\tanh \frac{\lambda l}{2}-\left(l_{1}-\frac{\sinh \lambda l_{1}}{\lambda \cosh \frac{\lambda l}{2}}\right)\right. \\
\left.\left\{\frac{\sinh \lambda l_{1} \cdot \frac{2 e^{\frac{\lambda l}{2}}}{1+e^{\lambda l}}}{l_{1}-\frac{\sinh \lambda l_{1}}{\lambda} \cdot e^{\lambda l_{1}} \cdot \frac{1+e^{\lambda l_{2}}}{1+e^{\lambda l}}}\right\}\right) \cdots \cdots \cdots
\end{gathered}
$$

\begin{tabular}{|c|c|c|c|c|c|c|c|c|c|c|}
\hline \multirow{2}{*}{ 種＼cjkstart類 } & \multirow{2}{*}{$\begin{array}{l}\text { 鋼 索 径 } \\
d_{r} \mathrm{~mm}\end{array}$} & \multirow{2}{*}{$\left|\begin{array}{c}|c| \\
\text { 線 径 } \\
d \mathrm{~mm}\end{array}\right|$} & 撚 & b & \multirow{2}{*}{$\left|\begin{array}{l}E \cos ^{2} \omega_{r} \\
\cos ^{2} \omega_{s} \\
\mathrm{~kg} / \mathrm{mm}^{2}\end{array}\right|$} & \multirow{2}{*}{\begin{tabular}{|l}
$A_{r} \mathrm{~mm}^{2}$ \\
\end{tabular}} & \multirow{2}{*}{$\left|\begin{array}{l}\text { 断面二次 } \\
モ \\
\text { Ir } \mathrm{mm}^{4}\end{array}\right|$} & \multirow{2}{*}{$\mid \begin{array}{l}\mid \\
S_{r} \mathrm{t}\end{array}$} & \multirow{2}{*}{$\begin{array}{c}l \\
\mathrm{~mm}\end{array}$} & \multirow{2}{*}{$\begin{array}{l}l_{2} \\
\mathrm{~mm}\end{array}$} \\
\hline & & & $\left|\begin{array}{c}-7 \\
\omega_{r}\end{array}\right|$ & 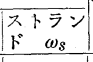 & & & & & & \\
\hline$\overline{6 \times 7 \mathrm{C} / \mathrm{L}}$ & 26.0 & 2.86 & $14^{\circ} 33^{\prime}$ & $11^{\circ} 14^{\prime}$ & 18,930 & 269.8 & $3 \quad 11,025$ & 41.80 & 1,686 & 346 \\
\hline 7 SRAF & 24.7 & 2.50 & $15^{\circ} 14^{\prime}$ & $11^{\circ} 34^{\prime}$ & 18,400 & 269.8 & 8,816 & 41.30 & 1,686 & 346 \\
\hline
\end{tabular}

\section{第1表 試}

$56 \times 7 \mathrm{C} / \mathrm{L}$ 鋼索では横荷重 $Q$ の作用点真下の $\mathrm{a}$ 位置のほ か, b, f, cの各位置に, $6 \times 7 \mathrm{SRAF}$ 鋼索では $\mathrm{c}, \mathrm{e}$ 位置にヒ ズミ計をはりつけることが困難だつたので，a位置のほ かはb位置にのみにヒズミ計をはりつけた。

な㧈 $6 \times 7 \mathrm{SRAF}$ 鋼索の場合外層素線が異形線であるから， 既報11のように修正係数1.10をか汀叔ばならない。

$2 \cdot 1 \cdot 2$ 測定結果と考察 張力 $S$ が大になると鋼索の素 線相互間の摩擦が増大するため鋼索の曲げ剛性弾性率 $E_{f}$ は増大する。また横荷重Qが大になり曲げモーメン ト $M_{b}$ が大になると素線相互の滑りが大となり $E_{f}$ は隇少 する。鋼索の曲げ岡性が変化すると曲价応力状態図が第 3 図に示すように変化する。

(a)の場合は $\sigma_{b}=E \frac{d r}{2 \rho},(d) の$ 場合は $\sigma_{b}=E_{b} \frac{d}{2 \rho}$ (b), (c) の場合の $\sigma_{b}$ はもつと複雑な式で表わされる。 いま一般に

$$
\sigma_{b}=E_{b}-\frac{k d}{2 \rho}
$$

とすると， $k^{*}$ 注として素線相互の滑りの程度によつて 変化する。ヒズミ計で測定して得られた $\sigma_{b}$ おび(5)式 の $\rho$ を用い $E_{b}$ として完全滑動の際の值をとるとkが計算 できる。

鋼索の曲げ岡性 $E_{f} I_{r}$ において $I_{r}$ を断面分離の如何にか かわらず一定 (断面固着のときの值) とすると $E_{f}$ が曲げ ・剛性を表わす指標となる。

第 4,5 図は測定結果から得られた $E_{f}$ $k$ の関倸図で亦 る。ここで $E_{b}$ の值としては従来の測定個所における完 全滑動の際の測定值を基準にとり $E_{3}=10,000 \mathrm{~kg} / \mathrm{mm}^{2}$ と しだ。また第 4,5 図は張力 $S$ がそれぞ れ $1,2,3$ tのときの值を記入したもので あるが，そ机らの值を張力別には区別 しなかつた。というのは $S$ の変化にか かわらず $k$ はほほ洁同一曲線上にのろか らである。

これらの図から

$$
\frac{1}{\rho}=-\frac{Q}{2 S} \lambda\left(1-K e^{\frac{-\lambda l_{2}}{2}}\right) .
$$

$\lambda$ が比較的小さいときは $K$ の代りに男をおく。 実験に使用した試料は第 1 表のようである。

ヒズミ計のはりつけ個所を第 2 図a,bに示す。すなわ

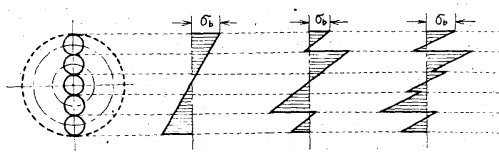

(a) (b)

(c)
第3図曲げモーメントの增大に伴了断面分離 と曲げ応力状態図

\footnotetext{
《良曲げ応力の大きさを表わするのではない。その理由は曲げ剛性が大 きくなつてkが增大すると一定の横荷重に対して $\rho$ る大きくなり，結局 のるはあまり変化しないからである。
}

1）曲汸応力aは位置より b, f 位置が大きい。それより さらにc, e位置が大きくなつている(ただしc, e位置では 圧縮応力）。すなわち断面完全滑動の際の $E_{b}$ は $6 \times 7 \mathrm{C} / \mathrm{L}$ $12,000 \sim 14,000 \mathrm{~kg} / \mathrm{mm}^{2}$, c 位置では $15,000 \sim 17,000 \mathrm{~kg} /$ $\mathrm{mm}^{2}$ となる。6×7 $\mathrm{SRAF}$ では a 位置で $10,000 \mathrm{~kg} / \mathrm{mm}^{2}, \mathrm{~b}$ 位置で $16,000 \sim 17,000 \mathrm{~kg} / \mathrm{mm}^{2}$ となる。

2） a 位置では概して曲げ岡性の大きいときでも $k$ は 小さく 1 に近い。この理由鋼索の曲げに伴う断面分離 の進行順序と断面変形によつて説明できるものと考えら れる。 が理論的に解析しているように，まず最初に側ストラン ド間 $\mathrm{EF}$ あるいは $\mathrm{BC}$ 亿生じ，そ机からAあるいはD の $\mathrm{a}$ 位置では $10,000 \mathrm{~kg} / \mathrm{mm}^{2}$ ではあるが， b, f位置では，

すなわち第2 図、において鋼索断面分離は，Czitary 


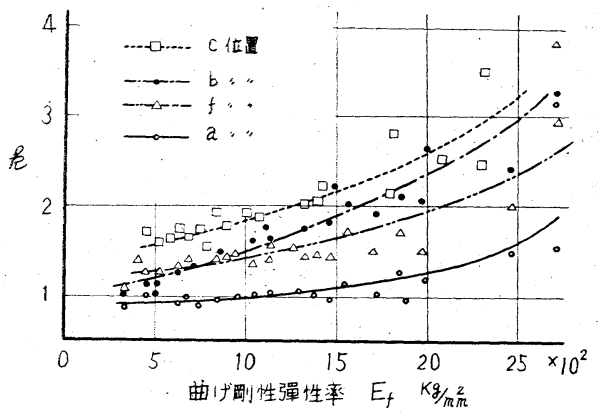

第 4 図 $6 \times 7 \mathrm{C} / \mathrm{L} 26.0 \mathrm{~mm}$ の $E_{f}-k$ 線园

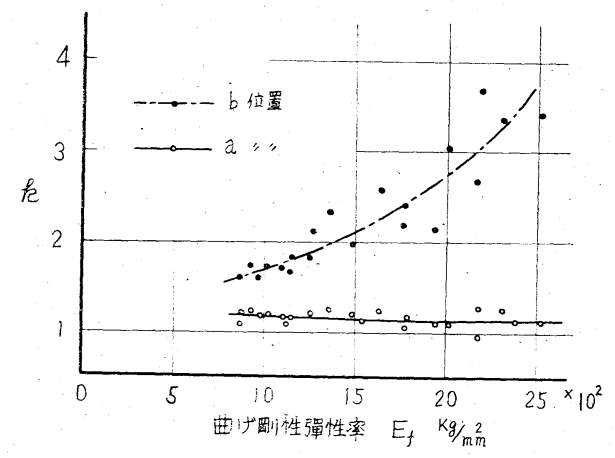

第5図 $6 \times 7 \mathrm{SRAF} 24.7 \mathrm{~mm}$ の $E_{f}-k$ 線図

トランドの方向に進むのであるが，実際には鋼索断面全 体においてAが引張り側，Dが圧縮側であるためまず $\mathrm{A}$ Fあるいは AB間に断面分離が生じ，それが次第にDの 方向に進むものと考えられる。このためAストランドも 比較的早く分離するのに対してDストランドは $\mathrm{E}, \mathrm{C}$ ス トランドによつて締めつけられるような状態となるか ら,Dストランド中の素線間分離は遅れる。このような断 面分離の進行順序によつて鋼索の曲げ岡性が相当に大き いときでも，Aストランドは断面分離が進行しているの で、位置の $k$ は小さくほぼ 1 に近いということになる。

また b, $\mathrm{f}$ 位置より $\mathrm{c}, \mathrm{e}$ 位置の $k$ が大きくなる可能性 も理解できる。次にAあるいはDストランドが麻心の方 向に喰いこみ $\mathrm{B}, \mathrm{F}$ ストランドが多少横に広がる断面分 離によつて a 位置は曲率が減じ， b, f 位置は曲率が大き くなる。c, e 位置の曲率は幾分減しる。この結果 $\mathrm{a}$ 位置 の曲げ応力は減し，完全滑動の際に $E_{b}=10,000 \mathrm{~kg} / \mathrm{mm}^{2}$ 前後というように小さくなつたものと思われる。

このような断面の分離進行順序と変形は鋼索の構造, 種類, 製造時の状態等によつて左右され, 極めて複雑な様 相を呈するものと思われるが，概略的には一応以上のよ

第2表 試 料

\begin{tabular}{|c|c|c|c|c|c|c|c|}
\hline \multirow{2}{*}{ 種，類 } & \multirow{2}{*}{$\begin{array}{l}\text { 公称径 } \\
d_{r} \mathrm{~mm}\end{array}$} & \multirow{2}{*}{$\begin{array}{l}\text { 実測径 } \\
d_{r} \mathrm{~mm}\end{array}$} & \multirow{2}{*}{$\begin{array}{c}\text { 素線径 } \\
d \mathrm{~mm}\end{array}$} & \multicolumn{2}{|c|}{ 撚 り 角 } & \multirow{2}{*}{$\begin{array}{c}\text { 断面積 } \\
A_{r} \mathrm{~mm}^{2}\end{array}$} & \multirow{2}{*}{$\begin{array}{c}\text { 切断荷重 } \\
S_{r}{ }^{t}\end{array}$} \\
\hline & & & & $\begin{array}{c}\square-7^{\circ} \\
\omega_{r}\end{array}$ & $\mid \begin{array}{c}\pi+5 ン \\
ト \\
F\end{array}$ & & \\
\hline $\begin{array}{l}7 \text { 本然り } \\
6 \times-\mathrm{C} / \mathrm{L}\end{array}$ & $\begin{array}{l}12.0 \\
28.0 \\
\end{array}$ & $\begin{array}{l}12.2 \\
29.4\end{array}$ & $\begin{array}{l}3.98 \\
3.08\end{array}$ & $15^{\circ} 25^{\prime}$ & $\begin{array}{l}10^{\circ} 50^{\prime} \\
10^{\circ} 50^{\prime}\end{array}$ & $\begin{array}{l}86.3 \\
313\end{array}$ & $\begin{array}{l}10.8 \\
47.5\end{array}$ \\
\hline
\end{tabular}

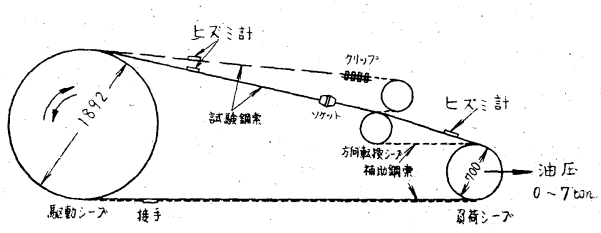

第6 図 引張り曲げ試験装置(II)

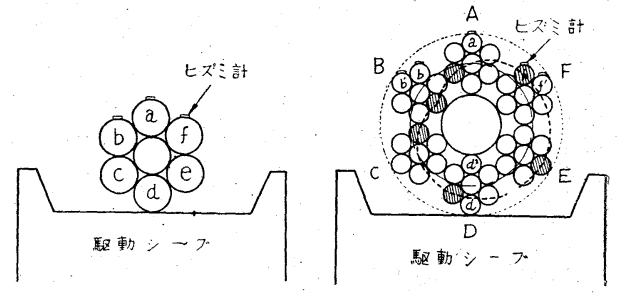

第7図ヒズミ計貼付位置

うな過程を経るむのと考えて差しつかえないであろう。

\section{$2 \cdot 2$ シーブによる引張り曲げ試験}

$2 \cdot 2 \cdot 1$ 試料之試験方法 試験装置は第 6 図に示すよ らである。油圧引張り装置の最大引張力は約 $7 \mathrm{t}$ である から，鋼索には最大 $3.5 \mathrm{t}$ まで張力をかけることができ る。鋼索の曲げは駆動シーブを回転させることによつて 与えられる。

実験に使用した材料は第 2 表のようである。

駆動シーブの溝形は第 7 図に示寸ようであるが，負荷 シーブの溝形は直径 $26 \mathrm{~mm}$ の半円形であるので, $6 \times 7$ $\mathrm{C} / \mathrm{L} 28.0 \mathrm{~mm}$ の場合は溝形に接せす側方から支えられた 形となる。ヒズミ計は $2 \cdot 1$ 節と同様 $\mathrm{S}_{121} \mathrm{~B}$ で接着剂とし ては速乾性の SP-3 を用い，第 $7 \mathrm{a}, \mathrm{b}$ 図に示すようには りつけた。

$2 \cdot 2 \cdot 2$ 測定結果と考察 シーブ上での曲げの場 合 鐦 索はほぼ完全に断面が分離するので $\sigma_{b}=E_{b} \frac{d}{D}$ として表 わし，曲げ応力の大きさを $E_{b}$ で示すと第 8,9 図のよう になる。 $\frac{D}{d}$ に大り方が駆動シーブ上での，小さい方が 負荷シーブ上での曲げを表わす。

$2 \cdot 1$ 節と同様に曲げ応力は第 7 図において a 位置よ りもb,f位置の方が大きいことが認められる。しかして 本撚りでは同一素線中の僅かに離れた $\mathrm{a}$ 位置とb位置で はほぼ等しい応力が生じている場合があり, 一般に $\sigma_{b}$ はbおよびf 位置の方が a 位置よりも大きいようであ るが，はつきりとその傾向を指摘することは困難である ように思われる。これに詨し， $6 \times 7 \mathrm{C} / \mathrm{L}$ の実験結果は多

第 3 表 断面変形による側方への鋼索径增大量

\begin{tabular}{c|c|c|c|c}
\hline \multirow{2}{*}{ 種類 } & \multicolumn{4}{|c|}{ 鋼采径增大量 $1 / 100 \mathrm{~mm}$} \\
\cline { 2 - 4 } & 7 本撚り $12 \mathrm{~mm}$ & $6 \times 7 \mathrm{C} / \mathrm{L} 14 \mathrm{~mm}$ & $6 \times 7 \mathrm{C} / \mathrm{L} 28 \mathrm{~mm}$ & $6 \times 19 \% 14 \mathrm{~mm}$ \\
\hline $1 \mathrm{t}$ & 0.3 & 2.3 & 7.3 & 2.0 \\
$2 \mathrm{t}$ & 1.3 & 3.5 & 10.0 & 2.0 \\
$3 \mathrm{t}$ & 2.3 & 5.0 & 10.0 & 3.8 \\
\hline
\end{tabular}




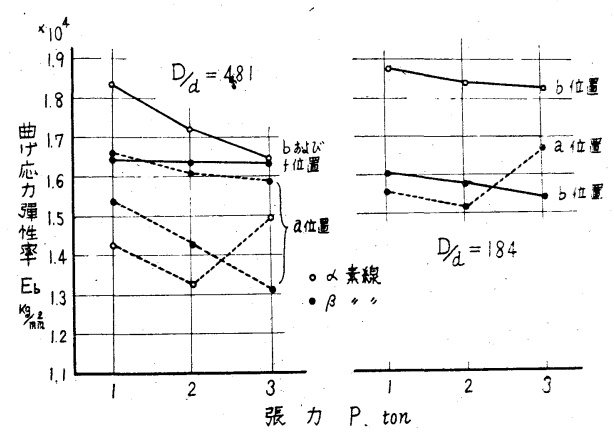

第 8 図 7 本撚り $12.0 \mathrm{~mm}$ 曲げ試験結果

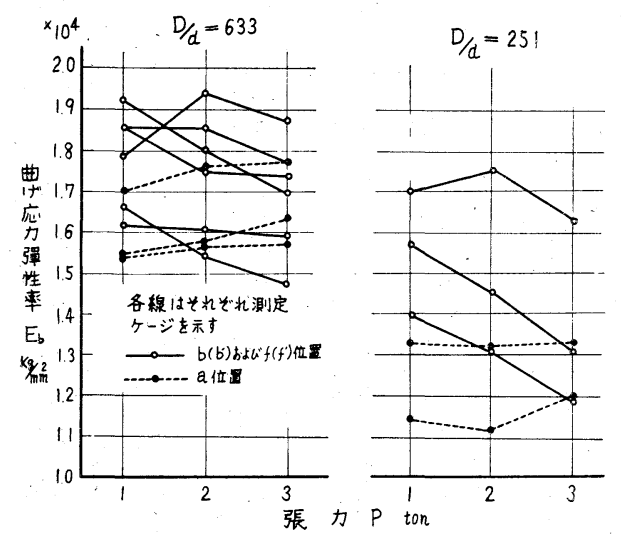

第 9 図 $6 \times 7 \mathrm{C} / \mathrm{L} 28.0 \mathrm{~mm}$ 曲げ試験結果

くのヒズミ計を $\mathrm{a}$ 位置あるいは $\mathrm{b}\left(\mathrm{b}^{\prime}\right)$ および $\mathrm{f}\left(\mathrm{f}^{\prime}\right)$ 位 置に任意にはりつけたもので, 概して 7 本撚りの実験結 果よりはつきりと上述の傾向をもつように思われる。こ れは $6 \times 7 \mathrm{C} / \mathrm{L}$ の断面変形が大きいためと考えられる。第 3 表は断面変形による鋼索径変形量を示すものである。

第 3 表より $6 \times 7 \mathrm{C} / \mathrm{L}$ の方が 7 本撚りに比べ断面変形 が大きいことが認められる。

$\mathrm{a}$ 位置よりも b あるいは $\mathrm{f}$ 位置の方が曲げ応力が大き い理由は $2 \cdot 1$ 節で考察したように 鋼索断面の分離進行 順序と変形によるものと考えられる。

以上の実験結果より従来測定していた個所は最大曲げ 応力発生個所ではなく，かえつて小さい曲げ応力発生個 所であることが示されたのであるが，それではどこが最 大曲げ応力発生個所であり，そこにはどの程度の曲げ応 力が発生するのかということが問題となる。

これは鋼索構造, 曲げの程度, その他多くの要素に支 配され簡単に論じられないのであるが，6×7鋼索ではた とえば第 7 図の $\mathrm{d}^{\prime \prime \prime}$ 位置に生じることが考えられよら。 この位置の内側はストランドの遅い分離によつて大きい 引張り応力を生じ, 断面分離後は断面変形によつてやは り大きい引張り応力を生しる。

結局, $E_{b}$ の值としては鋼索断面が最初より完全滑動 するものとし，ただ撚りの影響のみを考慮するとき, 理
論的には $E \cos ^{2} \omega_{r} \cdot \cos ^{2} \omega_{s}$ がほぼ正しい值と考えられ るので，上述の鋼索断面分離進行順序と分離に伴う断面 変形による $E_{b}$ の増大を考慮すると $E_{\boldsymbol{b}}=20,000 \mathrm{~kg} / \mathrm{mm}^{2}$ 程度は見込む必要があると考えられる。

\section{3. 結 言}

本研究は現在論議の的となつている鋼索の曲げ応力弾 性率 $E_{b}$ を強力作用下の鋼索の曲げ試験によつて直接測 定したものであるが，その際曲げに伴う断面の分離進行 順序と変形を考慮することによつて最大曲げ応力発生個 所に 1 つの示唆が得られ，鋼索の曲げ応力弾性率の決定 に 1 つの寄与をすることができたものと考える。

本研究を要約すれば次のようである。

1）鋼索は曲げた際に素線相互間が滑動し，断面が分 離すると同時に断面の変形が生じる。

2）この断面の分離進行順序と変形のために，断面の 位置によつて曲げ応力が大きくなる個所と小さくなる個 所とが生じる。従来測定していた個所は曲げ忍力が小さ くなる個所である。

3）曲げ応力の大きくなる個所に対しては， $E_{b}=20$, $000 \mathrm{~kg} / \mathrm{mm}^{2}$ はとる必要があろう。したがつて 鉱山保安 規則の $E_{b}=10,000 \mathrm{~kg} / \mathrm{mm}^{2}$ は修正しなければならない と考えられる。

\section{考文 献}

1) G. v. Bach: Maschinenelemente, 1881 1913 この他 V.S.I., S。 $1752,1902$.

2) O. Benoit: Die Drahtseilfrage, Leipzig, 1915.

3) J. Hrabák: Die Drahtseile, 1902.

4) J. Isaacksen: Die Berechnung der Drahtseilen, V.D.I., Bd. 51, Nr. 17, 27. April 1907, S. 652 657.

5) H. Bock: Die Bruchgefahr der Drahtseile, Glückauf, Jg. 45, 1909.

6) R. Woernle: Ein Beitrag zur Klärung der Drahtseilfrage, V.D.I. 73 (1929) S. $417 ; 75$ (1931) S. $1485 ; 77$ (1933) S. 802.

7) W. A. Scoble : 1st 5th Report of Wire Rope Research Comittee, Proc. of I.M.E. Vol. 115, 1920, p. 835 868; Vol 119, 1924, p. 1193 1220; Vol. 123, 1928, p. 353 4C4; Vol 125, 1930, p. 553 602; Vol 130, 1935, p. 373 478.

8) Shoji Ikeda, Isao Ueno: Equivalent Bending and' Torsional: Rigidity of Wire Rope and Stress Induced in Elementary Wire of Wire Rope when it is Bent along the Sheave, Proc. of 1st Japan National Congress for App. Mech. 1951 p. 199.

9) 水田準一: 立坑卷綱の安全率について, 旅順工大紀要 12 巻 5 号, 昭 和14年

10) Taichiro Ogawa: A New Index to control Cable Endurance, 東大航研報告, Vol. 4, No. 49.

11) 三雲英之助・会田俊夫・浅岡喜久雄 $:$ 鋼索の曲げ応力弾性率につい て, 日本鉱業会誌 69 巻 783 号 345 348頁。この他会田俊夫・佐藤進： 鋼索の曲げ応力に関するー・二の問題, 第6 回ワイヤロープ研究会 講演集63 72頁

会田俊夫・佐藤進 : 引張り荷重と横荷重による鋼索の曲け剛性抢よ び曲げ応力の変化, 水矅会誌 13 巻10号761 766頁 会田俊夫・佐藤進：引張り曲价試験による鋼索曲げ応力の測定, 水 矅会誌 13 巻 6 号, 昭和 33 年 $376 \sim 331$ 頁

12) Th. Wyss : Strahldrahtseile der Transport-und Förderanlagen insbesondere der Standseil-und Schwekebahnen, $1956 \mathrm{~S} .119$ $\sim 152$.

13) E. Czitary: Seilschwebebahnen, 1951, S. 75 103. 